\title{
Gravity, Aeromagnetic and Rock-property Data of the Central California Coast Ranges
}

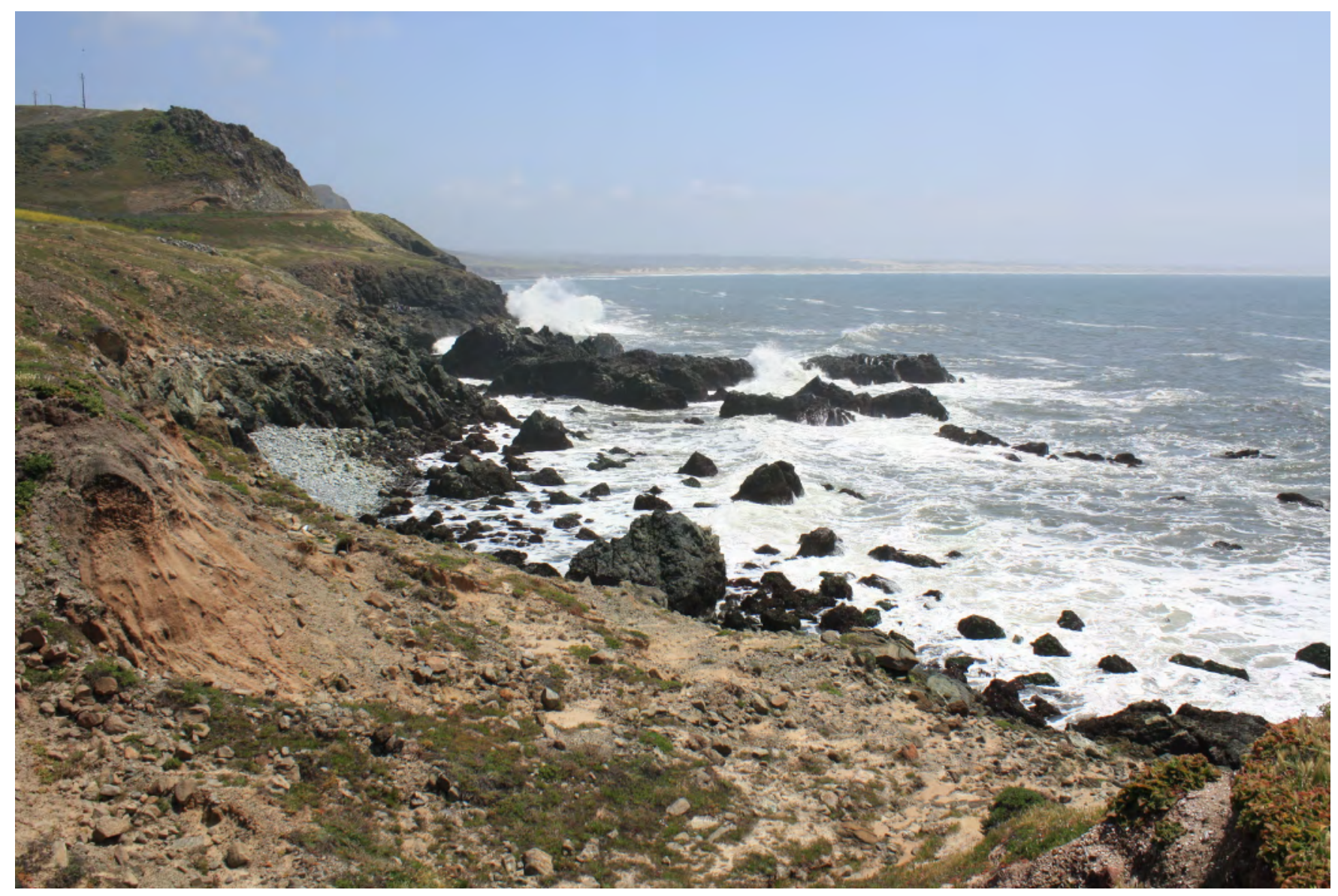

Open-File Report 2013-1282

U.S. Department of the Interior

U.S. Geological Survey 
COVER:

View near Point Sal, south along the central California coastline, of Coast Range ophiolite-a dense, magnetic rock type that is imaged well in gravity and aeromagnetic surveys. Photo by Victoria Langenheim. 


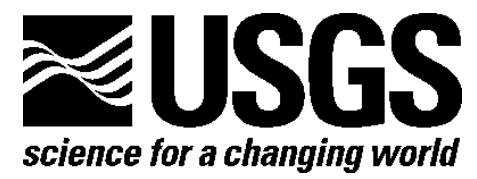

\section{Gravity, Aeromagnetic and Rock-property Data of the Central California Coast Ranges}

By V.E. Langenheim

Open-File Report 2013-1282

U.S. Department of the Interior U.S. Geological Survey 


\section{U.S. Department of the Interior \\ SALLY JEWELL, Secretary}

U.S. Geological Survey
Suzette M. Kimball, Acting Director

U.S. Geological Survey, Reston, Virginia: 2014

For more information on the USGS-the Federal source for science about the Earth, its natural and living resources, natural hazards, and the environment-visit http://www.usgs.gov or call 1-888-ASK-USGS

For an overview of USGS information products, including maps, imagery, and publications, visit $h$ ttp://www.usgs.gov/pubprod

To order this and other USGS information products, visit http://store.usgs.gov

Suggested citation:

Langenheim, V.E., 2014, Gravity, aeromagnetic and rock-property data of the central California coast ranges: U.S. Geological Survey Open-File Report 2013-1282, 12 p., http://dx.doi.org/10.3133/ofr20131282.

Any use of trade, firm, or product names is for descriptive purposes only and does not imply endorsement by the U.S. Government.

Although this information product, for the most part, is in the public domain, it also may contain copyrighted materials as noted in the text. Permission to reproduce copyrighted items must be secured from the copyright owner.

ISSN 2331-1258 (online) 


\section{Contents}

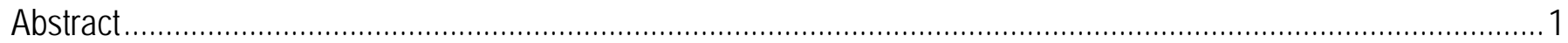

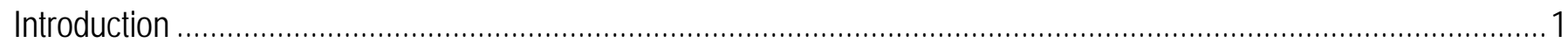

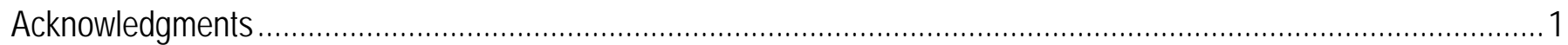

Gravity Data Sources, Reductions, and Accuracies................................................................................. 1

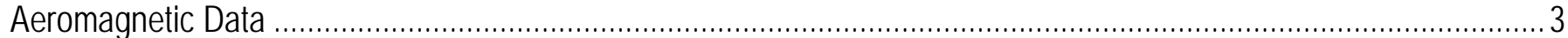

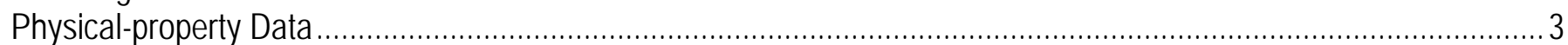

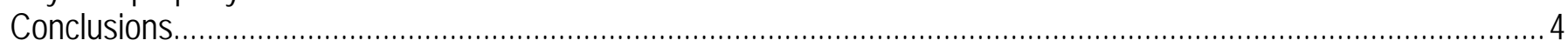

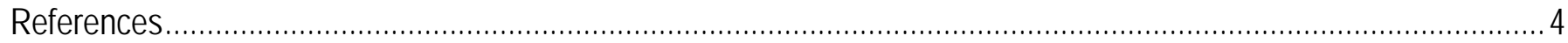

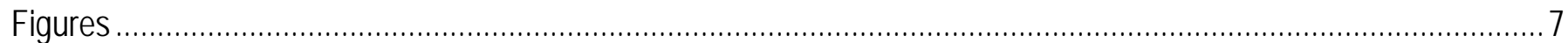

\section{Figures}

Figure 1. Index map of the central California Coast Ranges. Red lines indicate Quaternary faults modified from Jennings and Bryant (2010).

Figure 2. Gravity measurements in the central California Coast Ranges. Black lines indicate Quaternary faults modified from Jennings and Bryant (2010).....

Figure 3. Aeromagnetic surveys of the central California Coast Ranges. See table 1 for specifications..............9

Figure 4. Merged aeromagnetic map of the central California Coast Ranges. Magenta lines indicate Quaternary faults modified from Jennings and Bryant (2010).

Figure 5. Density and magnetic property measurements of the central California Coast Ranges. Red lines indicate Quaternary faults modified from Jennings and Bryant (2010).

\section{Tables}

Table 1. Aeromagnetic-survey specifications 


\title{
Gravity, Aeromagnetic and Rock-property Data of the Central California Coast Ranges
}

\author{
By V.E. Langenheim
}

\begin{abstract}
Gravity, aeromagnetic, and rock-property data were collected to support geologic-mapping, water-resource, and seismic-hazard studies for the central California Coast Ranges. These data are combined with existing data to provide gravity, aeromagnetic, and physical-property datasets for this region. The gravity dataset consists of approximately 18,000 measurements. The aeromagnetic dataset consists of total-field anomaly values from several detailed surveys that have been merged and gridded at an interval of $200 \mathrm{~m}$. The physical property dataset consists of approximately 800 density measurements and 1,100 magnetic-susceptibility measurements from rock samples, in addition to previously published borehole gravity surveys from Santa Maria Basin, density logs from Salinas Valley, and intensities of natural remanent magnetization.

\section{Introduction}

The central California Coast Ranges are located between the San Francisco and Los Angeles metropolitan areas (fig. 1). Although not as populous as those metropolitan areas, this region hosts major agricultural areas that depend heavily on groundwater, such as the Salinas, Santa Maria, and Cuyama Valleys. The region is also traversed by multiple northwest-striking to west-northwest-striking faults, the geometry of which has been a source of controversy. Potential-field data are an important component for modeling basin and fault geometry; in the central California Coast Ranges, the data in this report have been used to constrain the geometry and cumulative offset on some of the major faults, such as the San Gregorio-San Simeon-Hosgri and the Reliz-Rinconada Faults (Langenheim and others, 2013). Accompanying this report are gravity, aeromagnetic, and rock property datasets that were key for that analysis and can be useful for future water resource and seismic-hazard assessments.
\end{abstract}

\section{Acknowledgments}

We thank Pacific Gas and Electric Company and the National Cooperative Geologic Mapping Program for financial support. Darcy McPhee provided unpublished gravity data, Ed Mankinen supplied natural remanent magnetization data for the La Panza granite, Dan Scheirer provided a dozen density and magnetic-susceptibility measurements from the Carrizo Plain area, and Steve Kidder provided nearly pristine hand samples from the Salinian block for density and magnetic-susceptibility measurements. Geoff Phelps, Collin Cronkite-Ratcliff, and Sue Priest provided helpful reviews.

\section{Gravity Data Sources, Reductions, and Accuracies}

Gravity data in the central California Coast Ranges have been compiled from many sources. Previously collected onshore data (orange dots in fig. 2) were obtained from the compilation of Snyder and others (1982), which included measurements published as part of the California Division of Mines and Geology Bouguer gravity-map series at a scale of 1:250,000 (Bishop and Chapman, 1967; Burch and others, 1971; Hanna and Smith, 1974; Hanna and others, 1975; Rietman and Beyer, 1982) and as an 
isostatic-gravity map at a scale of 1:750,000 (Roberts and others, 1990). A significant source of onshore data is the Defense Mapping Agency (red dots in fig. 2); the agency not only compiled additional data, but also collected data on an approximate 1 mile grid south of latitude $36^{\circ} 15^{\prime} \mathrm{N}$. from the 1960 s to the 1980s. Additional data are from the U.S. Geological Survey (green dots in fig. 2) for the Monterey, Point Sur, and Paso Robles 1:100,000-scale quadrangles (Langenheim and others, 2002; McPhee and others, 2011; Watt and others, 2011) and from data collected for the Santa Maria and San Luis Obispo 1:100,000-scale quadrangles during 2008-2013.

Offshore data come from several sources. The most accurate data are from ocean-bottom measurements in the Monterey Bay area (Brooks, 1973; Cronyn, 1973; Souto, 1973; Spikes, 1973; Woodson, 1973; open, dark blue circles in fig. 2). The other two sources of offshore data are derived from ship-track data, do not include observed-gravity values, and are less precise in measurement and location. South of latitude $35^{\circ}$ N., data are from a 4-km grid (Beyer, 1980; open blue circles in fig. 2); north of latitude $35^{\circ} \mathrm{N}$., the data are from a 6-km free-air anomaly grid (Decade of North America Project, 1987; solid blue circles in fig. 2). These data are locally augmented by points digitized from intersections of Bouguer gravity-anomaly contours with track lines (Chapman and others, 1990; Pacific Gas and Electric Company, unpublished map).

Observed gravity values onshore and from ocean-bottom measurements were referenced to the International Gravity Standardization Net 1971 (IGSN71) gravity datum (Morelli, 1974). Free-air gravity anomalies were calculated by using the Geodetic Reference System 1967 formula for theoretical gravity on the ellipsoid (GRS67; International Association of Geodesy and Geophysics, 1971) and standard formulas for the free-air correction (Blakely, 1995; Telford and others, 1976). Bouguer, curvature, and terrain corrections (to a distance of $166.7 \mathrm{~km}$; Plouff, 1977) were applied to the free-air anomaly at each station to determine the complete Bouguer anomalies at a standard reduction density of $2,670 \mathrm{~kg} / \mathrm{m}^{3}$. Because topography is locally composed of low-density Cenozoic deposits, particularly in the Santa Maria Basin, the Gabilan Mesa, and the Irish Hills, the onshore data also were processed using a reduction density of $2,000 \mathrm{~kg} / \mathrm{m}^{3}$, which was chosen because it appeared to minimize correlation of topography composed of Neogene deposits with local gravity lows. An isostatic correction was then applied to remove the long-wavelength effect of deep crustal and/or upper mantle masses that isostatically support regional topography. The isostatic correction assumes an Airy-Heiskanen model (Heiskanen and Vening-Meinesz, 1958) of isostatic compensation; compensation is achieved by varying the depth of the model crust-mantle interface, using the following parameters: a sea-level crustal thickness of $25 \mathrm{~km}$, a crust-mantle density contrast of $400 \mathrm{~kg} / \mathrm{m}^{3}$, and a crustal density of $2,670 \mathrm{~kg} / \mathrm{m}^{3}$ for the topographic load. These parameters were used because (1) they produce a model crustal geometry that agrees with seismically determined values of crustal thickness for central California, and (2) they are consistent with model parameters used for isostatic corrections computed for the rest of California (Roberts and others, 1990). Furthermore, changing the model parameters does not significantly affect the resulting isostatic anomaly (Jachens and Griscom, 1985). The computer program ISOCOMP (Jachens and Roberts, 1981) directly calculates the attraction of an Airy-Heiskanen root by summing the attraction of individual mass prisms making up the root and thus calculating the isostatic correction; the resulting isostatic residual-gravity values should reflect lateral variations of density within the middle to upper crust.

The offshore data, except for the ocean-bottom measurements, do not have observed-gravity values. The track-line and gridded data consisted of either free-air or Bouguer anomaly values. For gridded data south of latitude $35^{\circ} \mathrm{N}$., and for track-line data, the free-air anomaly values were not available and, thus, were approximated by estimating the correction from the Bouguer gravity values using a digital terrain model of 1-minute and 3-minute data. For gridded data north of latitude $35^{\circ} \mathrm{N}$., free-air values were available, although it is not known which free-air formula was used to calculate 
these values. All the data were reduced to isostatic anomalies in the same way as for the onshore measurements.

The main sources of error are inaccurate elevations and/or inaccurate terrain corrections. Errors associated with terrain corrections may be 5-10 percent of the value of the total terrain correction. The average error based on the average terrain correction $(3.68 \mathrm{mGal})$ is about $0.4 \mathrm{mGal}$, but in the most rugged areas of the Santa Lucia Range, the individual errors may be as large as $4 \mathrm{mGal}$. Errors resulting from elevation uncertainties are probably less than $0.5 \mathrm{mGal}$ for most of the data because the majority of the stations are at or near bench marks and spot and surveyed elevations, which are accurate to about 0.1-3 m. Elevations of the subset of measurements collected by the U.S. Geological Survey were obtained using a GPS system with an accuracy of 1 or better, resulting in an anomaly accuracy of 0.18 $\mathrm{mGal}$ or better. Measurements for which elevations were controlled by contour interpolation are expected to have errors of up to $1.2 \mathrm{mGal}$. In general, the total uncertainties for the onshore and oceanbottom data shown on the map are estimated to be less than $2 \mathrm{mGal}$, although in many areas the data are considerably more accurate. The ship-track data are less accurate, with errors in the gravity measurement alone as high as $3 \mathrm{mGal}$ (Oliver, 1980, p. 4). For the ship-track data south of latitude $35^{\circ}$ N., McCulloch and others (1989) found that the crossing error was no greater than 4 mGal, with a majority of track-line crossings having a less than 1-2 mGal error.

\section{Aeromagnetic Data}

Aeromagnetic data are composed of several surveys (U.S. Geological Survey, 1980, 1987, 1996a, 1996b, 2001, 2005; Langenheim and others, 2009; Graymer and others, unpub. data; this report) that were flown at a nominal height of 150-305 m above ground along flightlines spaced 530-800 m apart (fig. 3; table 1). Accuracy of these surveys is $1 \mathrm{nT}$ or better. The aeromagnetic data were adjusted from their nominal height above ground to a common datum $305 \mathrm{~m}(1,000 \mathrm{ft})$ above ground. The base levels were adjusted to be the same and then we merged by smooth interpolation across survey boundaries to produce an aeromagnetic map of the study area (fig. 4). Magnetic data collected by helicopter at a nominal elevation of $50 \mathrm{~m}$ above ground for the Irish Hills (Langenheim and others, 2012) and by boat along the coast from San Simeon to Point Sal (Sliter and others, 2009, revised 2010) are available.

\section{Physical-property Data}

Density and magnetic properties of rock samples are crucial parameters for modeling gravity and magnetic data. Density measurements (orange dots on fig. 5) were compiled for the crystalline rocks of the Salinian Complex from Ross (1972, 1982) and for ophiolite at Point Sal from Kempner (1977). Rock samples were also collected in the central California Coast Ranges for rock-property analyses. Densities were determined by using a precision Sartorius electronic balance. All rocks were weighed dry in air (Wa), saturated in water (Ww), and saturated with water in air (Ws). From these measurements, grain density, dry-bulk density, and saturated-bulk density were calculated using the following formulas:

Grain density $=\mathrm{Wa} /(\mathrm{Wa}-\mathrm{Ws})$,

Dry bulk density $=\mathrm{Wa} /(\mathrm{Ws}-\mathrm{Ww})$, and

Saturated bulk density $=\mathrm{Ws} /(\mathrm{Ws}-\mathrm{Ww})$.

Also included in this report are density data from five borehole gravity surveys in the Santa Maria Basin (Beyer and others, 1985). Density logs from 11 boreholes in the central Salinas Valley (Tiballi and Brocher, 1998) are also provided. 
Magnetic susceptibilities (magenta dots in fig. 5) were measured by using a Geophysica KT-5 susceptibility meter and are reported to 0.1 to $0.01 \times 10-3$ SI units. The Geophysica KT-5 calculates volume susceptibility by assuming the sample shape is an infinite half-space. The instrument's ability to measure magnetic susceptibility is affected by surface roughness, weathering, and sample size, all of which can result in an underestimation of a sample's true susceptibility. The magnetic-susceptibility values reported represent the highest reading on the hand sample. Also included are natural remanent magnetization intensity measurements of ophiolite at Point Sal and Cuesta Ridge, of the Monterey Formation at Mussel Rock (Beebe, 1986; Nichols, 1978), and of the La Panza granite (Ed Mankinen, written commun., 2008). More detailed information on natural remanent magnetization of rocks from the Irish Hills is available (Langenheim and others, 2012).

\section{Conclusions}

Gravity, aeromagnetic, and physical property-data are compiled for use in geologic-mapping, water-resource, and seismic-hazard studies of the central California Coast Ranges. More than 14,000 gravity measurements onshore provide nearly uniform coverage south of latitude $36^{\circ} 15^{\prime} \mathrm{N}$. Offshore data consist of ocean-bottom measurements and gridded and contour-trackline intersection data from shiptrack measurements. The central California Coast Ranges have detailed, fairly uniform aeromagnetic data from multiple surveys flown at a maximum line spacing of $800 \mathrm{~m}$ and maximum flight height of $305 \mathrm{~m}$ above terrain. Density, magnetic-susceptibility, and natural remanent magnetization intensity measurements are also included as constraints for potential-field modeling.

\section{References}

Beebe, W.J., 1986, A paleomagnetic study of the southern Coast Range ophiolite, California and tectonic implications: Santa Barbara, University of California, Master's thesis, 148 p.

Beyer, L.A., 1980, Offshore southern California, in H.W. Oliver, ed., Interpretation of the gravity map of California and its continental margin: California Division of Mines and Geology Bulletin, v. 205, p. 8-15.

Beyer, L.A., Robbins, S.L., and Clutsom, F.G., 1985, Basic data and preliminary density and porosity profiles for twelve borehole gravity surveys made in the Los Angeles, San Joaquin, Santa Maria, and Ventura basins, California: U.S. Geological Survey Open-File Report 85-42, 66 p.

Bishop, C.C., and Chapman, R.H., 1967, Bouguer gravity map of California, Santa Cruz sheet: California Division of Mines and Geology, scale 1:250,000.

Blakely, R.J., 1995, Potential theory in gravity and magnetic applications: New York, Cambridge University Press, 441 p.

Brooks, R.A., 1973, A bottom gravity survey of the shallow water regions of southern Monterey Bay and its geological interpretation: Monterey, Calif., Naval Postgraduate School, Master's thesis, 90 p.

Burch, S.H., Grannell, R.B., and Hanna, W.F., 1971, Bouguer gravity map of California, San Luis Obispo sheet: California Division of Mines and Geology, scale 1:250,000.

Chapman, R.H., Chase, G.W., and Youngs, L.G., 1990, Bouguer gravity and magnetic anomaly map of the central California continental margin: California Continental Margin Geologic Map Series Central California Continental Margin Map no. 5C, scale 1:250,000.

Cronyn, B.S., 1973, Underwater gravity survey of northern Monterey Bay: Monterey, Calif., Naval Postgraduate School, Master's thesis, 53 p.

Decade of North American Geology Project, 1987, Gravity anomaly map of North America: Geological Society of America Map 2, scale 1:5,000,000. 
Graymer, R.W., Langenheim, V.E., Roberts, M.A., and McDougall, Kristin, in press, Geologic and geophysical map database of the eastern $3 / 4$ of the Cambria 30' X 60' quadrangle, Central California Coast Ranges: U.S. Geological Survey Scientific Investigations Map 3287, 27 p., scale 1:100,000.

Hanna, W.F., and Smith, A.R., 1974, Bouguer gravity map of California, Bakersfield sheet: California Division of Mines and Geology, scale 1:250,000.

Hanna, W.F., Rietman, J.D., and Biehler, S.H., 1975, Bouguer gravity map of California, Santa Cruz sheet: California Division of Mines and Geology, scale 1:250,000.

Heiskanen, W.A., and Vening-Meinesz, F.A., 1958, The Earth and its gravity field: New York, McGraw-Hill Book Company, Inc., 470 p.

International Union of Geodesy and Geophysics, 1971, Geodetic reference system 1967: International Association of Geodesy Special Publication no. 3, 116 p.

Jachens, R.C., and Griscom, A., 1985, An isostatic residual gravity map of California-A residual map for interpretation of anomalies from intracrustal sources in Hinze, W.J., ed., The utility of regional gravity and magnetic anomaly maps: Tulsa, Okla., Society of Exploration Geophysicists, p. 347-360.

Jachens, R.C., and Roberts, C.W., 1981, Documentation of a Fortran program, `ISOCOMP, for computing isostatic residual gravity: U.S. Geological Survey Open-File Report 81-574, 26 p.

Jennings, C.W., and Bryant, W.A., compilers, 2010, Fault activity map of California: California Geological Survey Geologic Data Map no. 6, map scale 1:750,000.

Kempner, W.C., 1977, The magnetic properties of the Point Sal ophiolite-A comparison with oceanic crust: Santa Barbara, University of California, Master's thesis, 124 p.

Langenheim, V.E., Jachens, R.C., Graymer, R.W., Colgan, J.P., Wentworth, C.M., and Stanley, R.G., 2013, Fault geometry and cumulative offsets in the central Coast Ranges, California-Evidence for northward increasing slip along the San Gregorio-San Simeon-Hosgri fault: Lithosphere, v. 5, p. 2948.

Langenheim, V.E., Jachens, R.C., and Moussaoui, K., 2009, Aeromagnetic survey map of the central California Coast Ranges: U.S. Geological Survey Open-File Report 2009-1044. Available at (http://pubs.usgs.gov/of/2009/1044.)

Langenheim, V.E., Stiles, S.R., and Jachens, R.C., 2002, Isostatic gravity map of the Monterey 30 X 60 minute quadrangle and adjacent areas, California: U. S. Geological Survey, Report: OF 02-0373, scale 1:100,000. Available at (http://geopubs.wr.usgs.gov/open-file/of02-373/).

Langenheim, V.E., Watt, J.T., and Denton, K.D., 2012, Magnetic map of the Irish Hills and surrounding areas, central California: U.S. Geological Survey Open-File Report 2012-1080, scale 1:24,000.

McCulloch, D.S., Beyer, L.A., and Childs, J.R., 1989, Free-air gravity anomaly map of offshore Santa Maria Basin, California, and adjacent areas: U.S. Geological Survey Open-File Report 89-322, scale $1: 250,000$.

McPhee, D.K., Langenheim, V.E., and Watt, J.T., 2011, Preliminary isostatic residual gravity anomaly map of Paso Robles 30 X 60 minute quadrangle, California: U.S. Geological Survey Open-File Report 2011-1104, scale 1:100,000 and data table. Available at (http://pubs.usgs.gov/of/2011/1104/).

Morelli, Carlo, ed., 1974, The International Gravity Standardization Net 1971: International Association of Geodesy Special Publication no. 4, 194 p.

Nichols, G.M., 1978, The seismic structure of the Pt. Sal ophiolite and its relationship to oceanic crustal structure: Santa Barbara, University of California, Master’s thesis, 155 p.

Oliver, H.W., 1980, Interpretation of the gravity map of California and its continental margin: California Division of Mines and Geology Bulletin v. 205, 52 p.

Plouff, Donald, 1977, Preliminary documentation for a FORTRAN program to compute gravity terrain corrections based on topography digitized on a geographic grid: U.S. Geological Survey Open-File Report 77-535, 45 p. 
Rietman, J.D., and Beyer, L.A., 1982, Bouguer gravity map of California-Santa Maria sheet:

California Division of Mines and Geology, scale 1:250,000.

Roberts, C.W., Jachens, R.C., and Oliver, H.W., 1990, Isostatic residual gravity map of California and offshore southern California: California Division of Mines and Geology, Geologic Data Map No. 7, scale 1:750,000.

Ross, D.C., 1972, Petrographic and chemical reconnaissance study of some granitic and gneissic rocks near the San Andreas fault from Bodega Head to Cajon Pass, California: U.S. Geological Survey Professional Paper 698, 92 p.

Ross, D.C., 1982, Results of instrumental neutron activation analyses for selected plutonic samples from the Salinian block, California Coast Ranges: U.S. Geological Survey Open-File Report 82-935, 16 p.

Sliter, Ray W., Triezenberg, Peter J., Hart, Patrick E., Watt, Janet T., Johnson, Samuel Y., and Scheirer, Daniel S., 2009, revised 2010, High-resolution seismic reflection and marine magnetic data along the Hosgri Fault Zone, central California: U.S. Geological Survey Open-File Report 2009-1100, version 1.1. Available at (http://pubs.usgs.gov/of/2009/1100/).

Snyder, D.B., Roberts, C.W., Saltus, R.W., and Sikora, R.F., 1982, A magnetic tape containing the principal facts of 64,026 gravity stations in the state of California: available from U.S. Department of Commerce, National Technical Information Service, document PB 82-168287, 34 p.

Souto, A.P.D, 1973, A bottom gravity survey of Carmel Bay, California: Monterey Calif., Naval Postgraduate School, Master's thesis, 68 p.

Spikes, C.H., 1973, A gravimetric survey of the Santa Cruz-Ano Nuevo Point continental shelf and adjacent coastline: Monterey Calif., Naval Postgraduate School, Master's thesis, 114 p.

Telford, W.M., Geldart, L.O., Sheriff, R.E., and Keyes, D.A., 1976, Applied Geophysics: New York, Cambridge University Press, 960 p.

Tiballi, C.A., and Brocher, T.M., 1998, Compilation of 71 additional sonic and density logs from wells in the San Francisco Bay area, California: U.S. Geological Survey Open-File Report 98-615, 132 p.

U.S. Geological Survey, 1980, Aeromagnetic map of the Los Padres area, California: U.S. Geological Survey Open-File Report 80-986, scale 1:62.500.

U.S. Geological Survey, 1987, Aeromagnetic map of the Hernandez-Parkfield area, southwest California: U.S. Geological Survey Open-File Report 87-92, scale 1:250,000.

U.S. Geological Survey, 1996a, Aeromagnetic map of the Carrizo Plain area on parts of the Bakersfield, Los Angeles, and San Luis Obispo 1 by 2 degree quadrangles, California: U.S. Geological Survey Open-File Report 96-692, scale 1:100,000.

U.S. Geological Survey, 1996b, Aeromagnetic map of the northern Gabilan Range area on part of the Monterey 1 by 2 degree quadrangle, California: U.S. Geological Survey Open-File Report 96-693, scale 1:100,000.

U.S. Geological Survey, 2001, Six aeromagnetic surveys in Nevada and California—A web site for distribution of data: U.S. Geological Survey Open-File Report 01-0145, accessed October 31, 2011, at http://pubs.usgs.gov/of/2001/ofr-01-0145/html/nevcal.html.

U.S. Geological Survey, 2005, Seven aeromagnetic surveys in California and Nevada-A web site for distribution of data: U.S. Geological Survey Open-File Report 2005-1328, accessed February 2, 2011, at http://pubs.usgs.gov/of/2005/1328/ca-nev.html.

Watt, J.T., Morin, R.L., and Langenheim, V.E., 2011, Isostatic gravity map of the Point Sur 30 by 60 minute quadrangle and adjacent areas, California: U.S. Geological Survey Open-File Report 20111036, scale 1:100,000. Available at (http://pubs.usgs.gov/of/2011/1036/).

Woodson, W.B., 1973, A bottom gravity survey of the continental shelf between Point Lobos and Point Sur, California: Monterey Calif., Naval Postgraduate School, Master’s thesis, 110 p. 


\section{Figures}

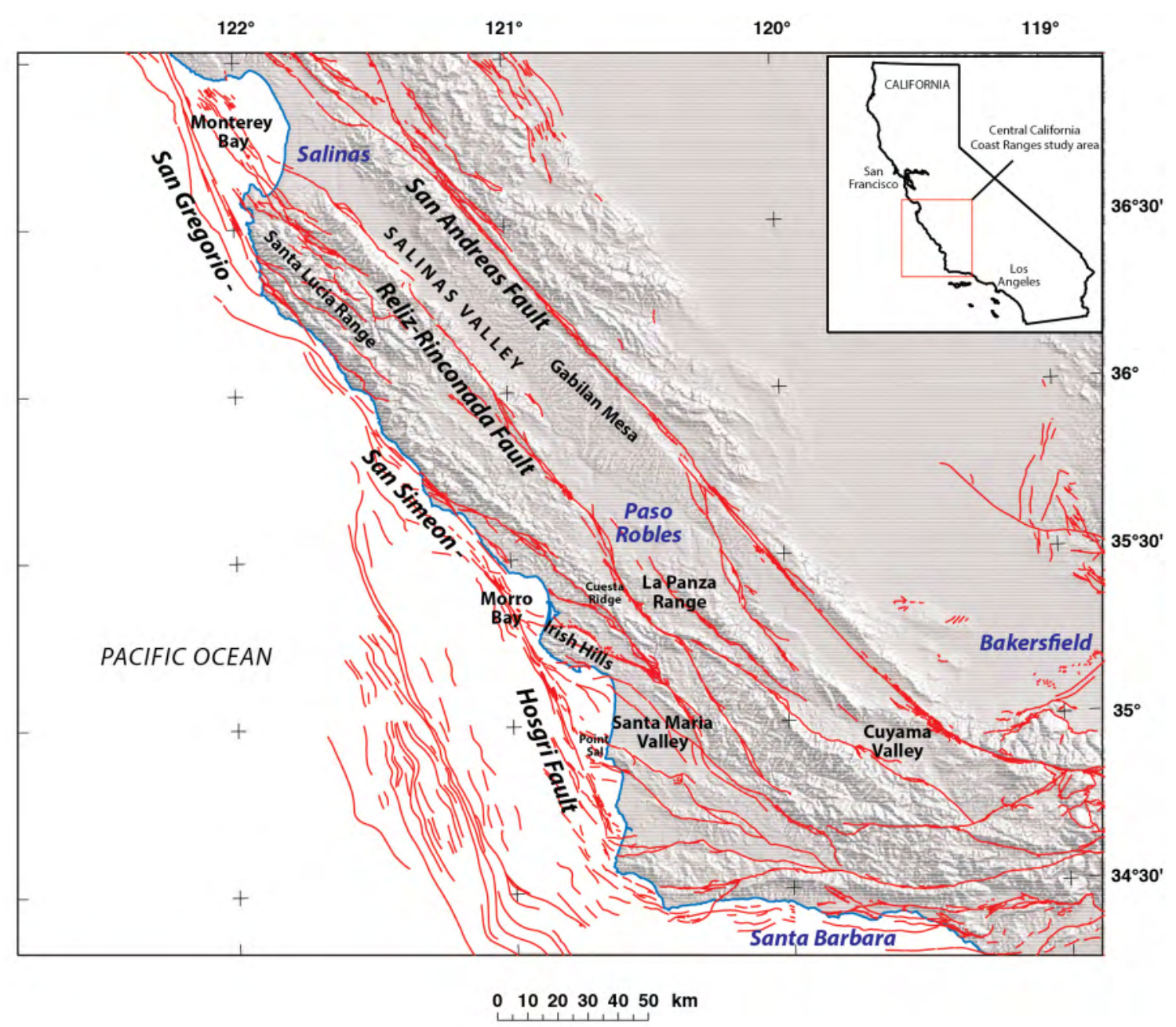

Figure 1. Index map of the central California Coast Ranges. Red lines indicate Quaternary faults modified from Jennings and Bryant (2010). 


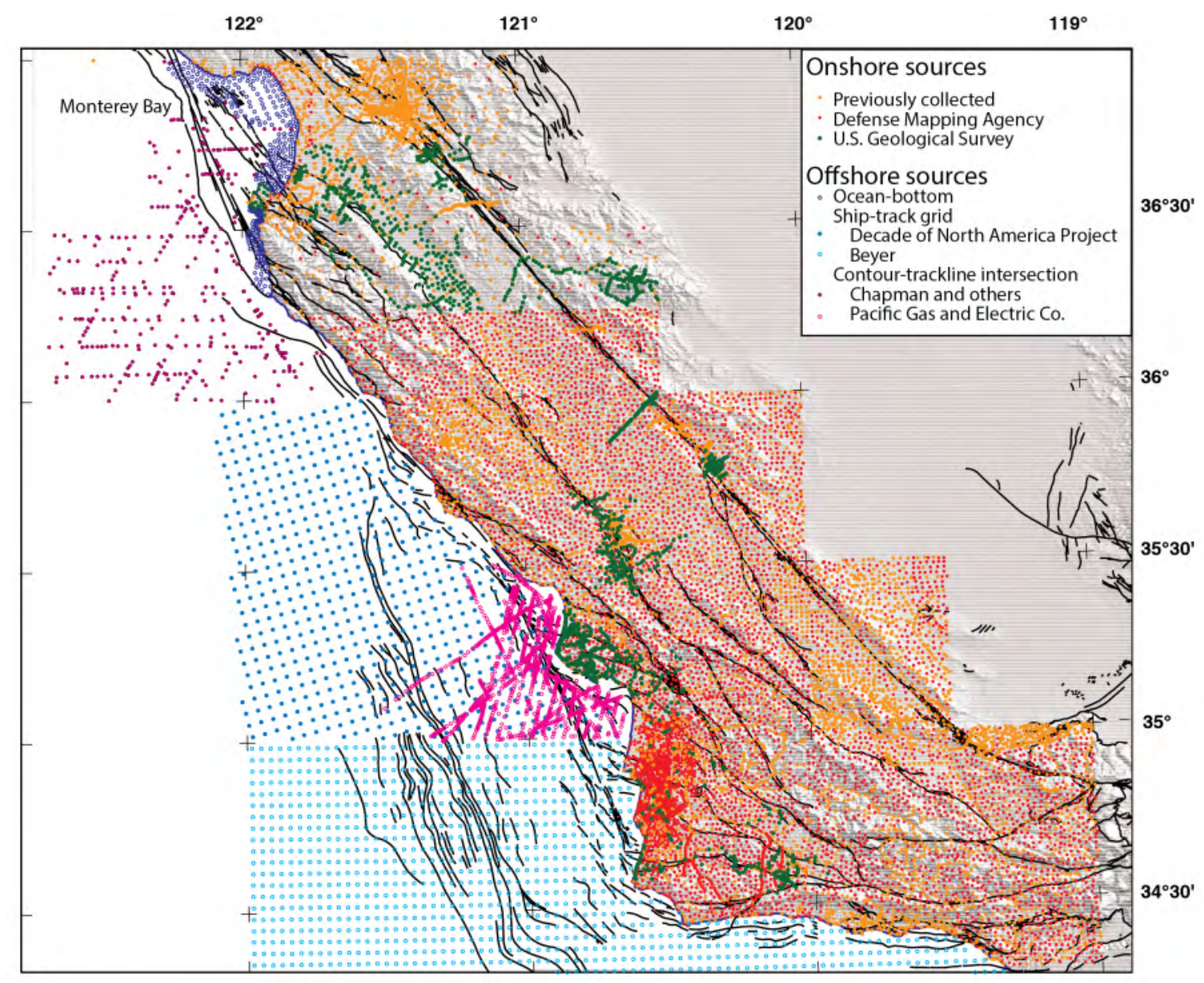

$\begin{array}{lllllll}0 & 10 & 20 & 30 & 40 & 50 & \mathrm{~km}\end{array}$

Figure 2. Gravity measurements in the central California Coast Ranges. Black lines indicate Quaternary faults modified from Jennings and Bryant (2010). 


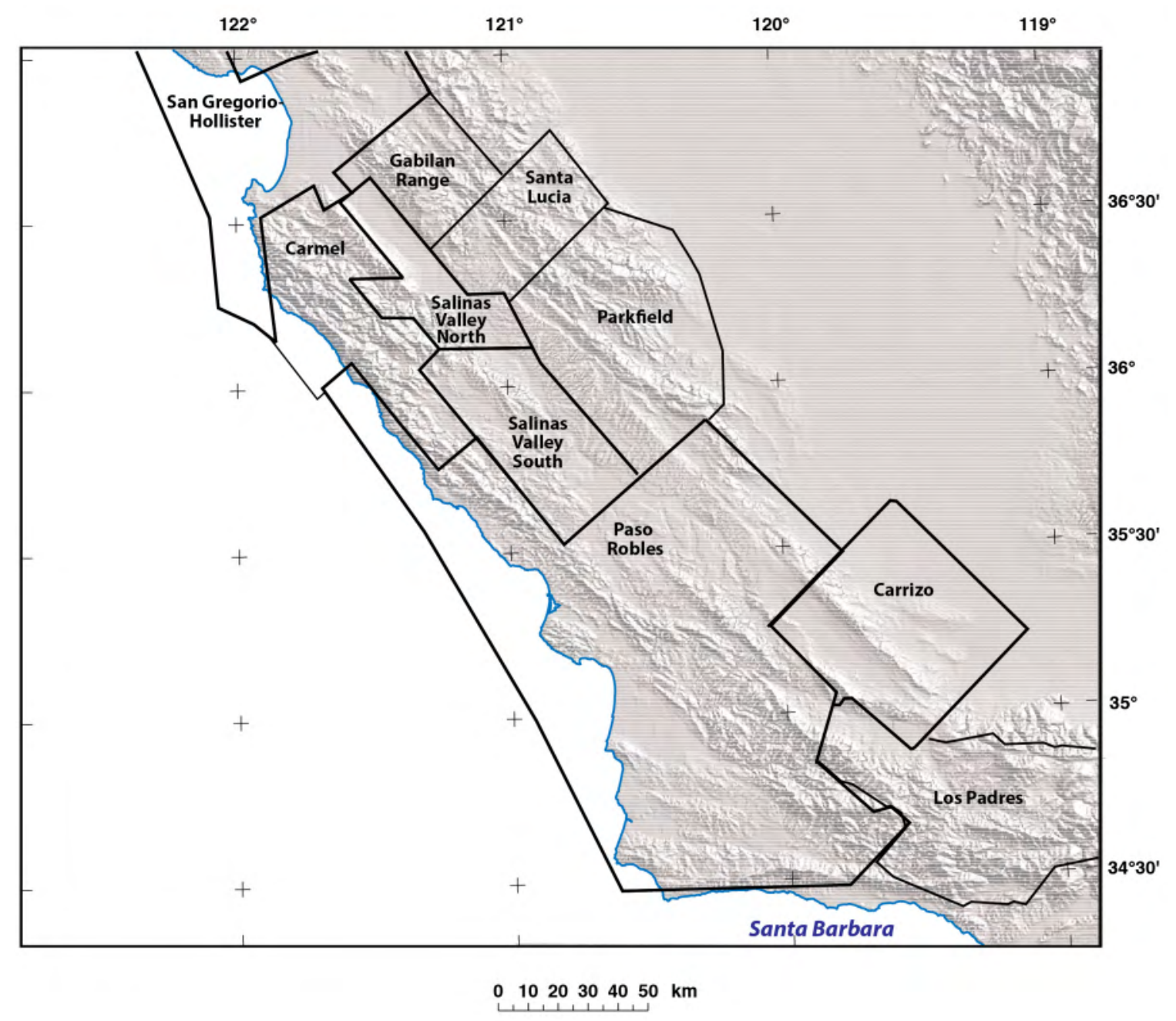

Figure 3. Aeromagnetic surveys of the central California Coast Ranges. See table 1 for specifications. 


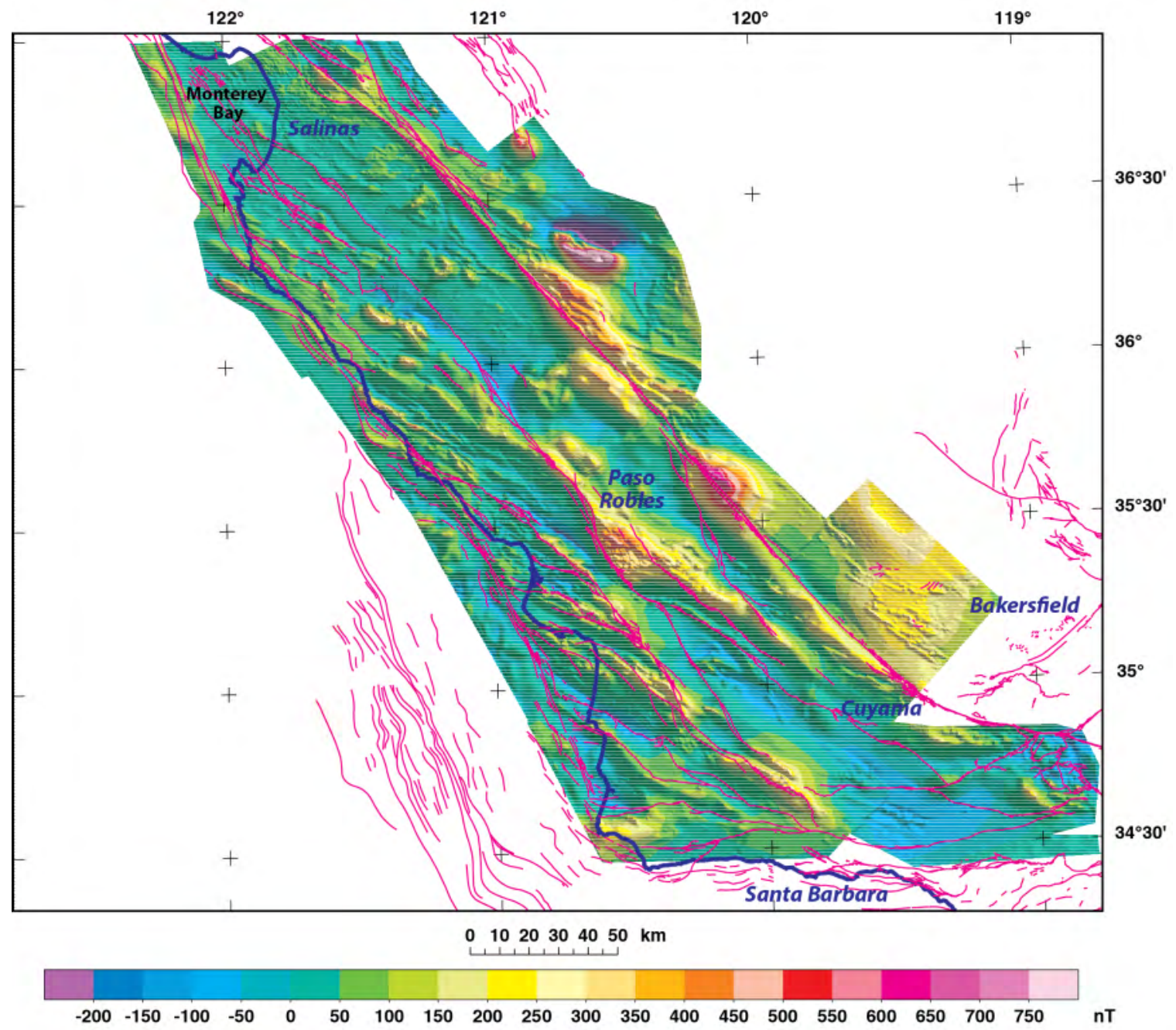

Figure 4. Merged aeromagnetic map of the central California Coast Ranges. Magenta lines indicate Quaternary faults modified from Jennings and Bryant (2010). 


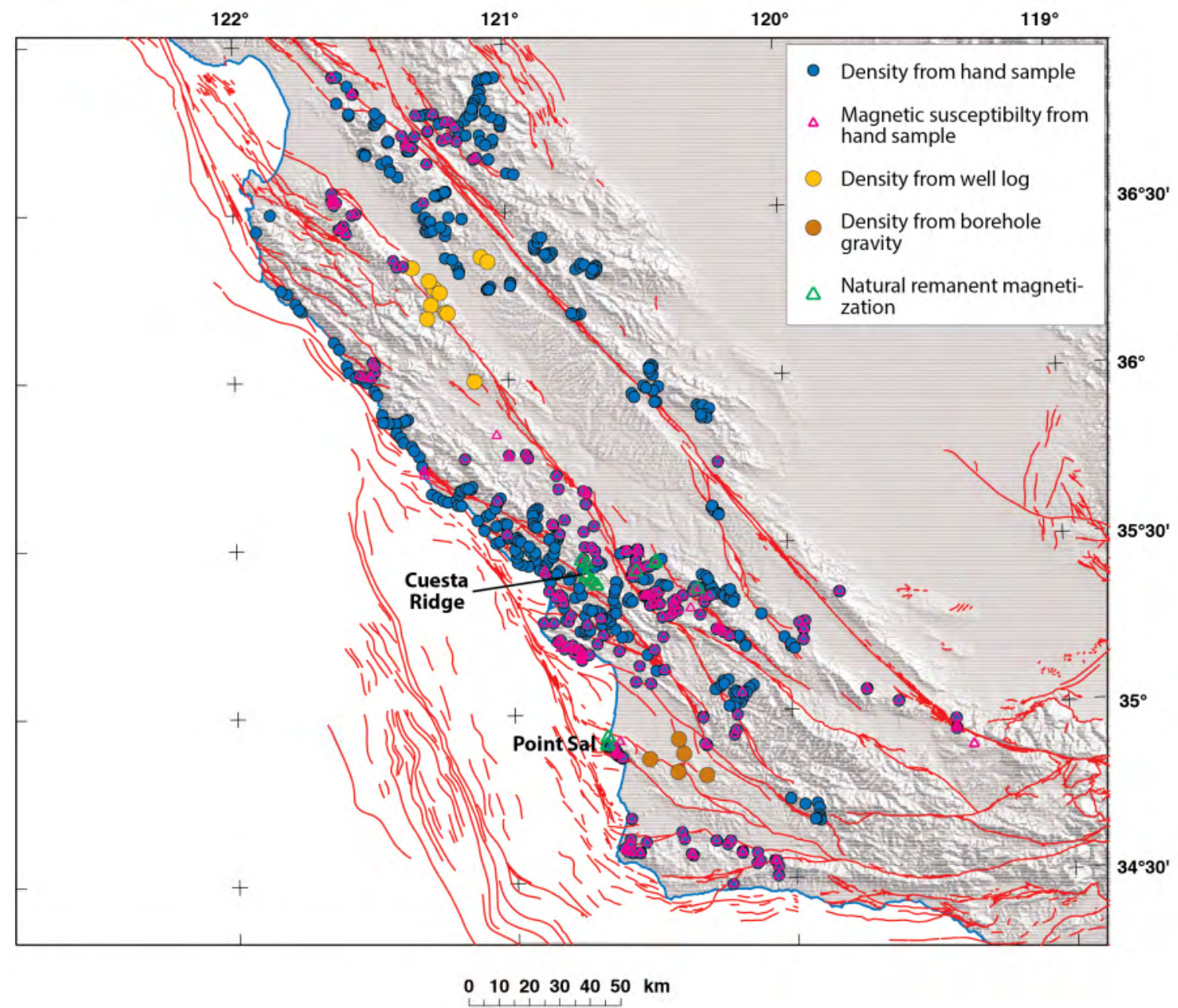

Figure 5. Density and magnetic property measurements of the central California Coast Ranges. Red lines indicate Quaternary faults modified from Jennings and Bryant (2010). 
Table 1. Aeromagnetic-survey specifications.

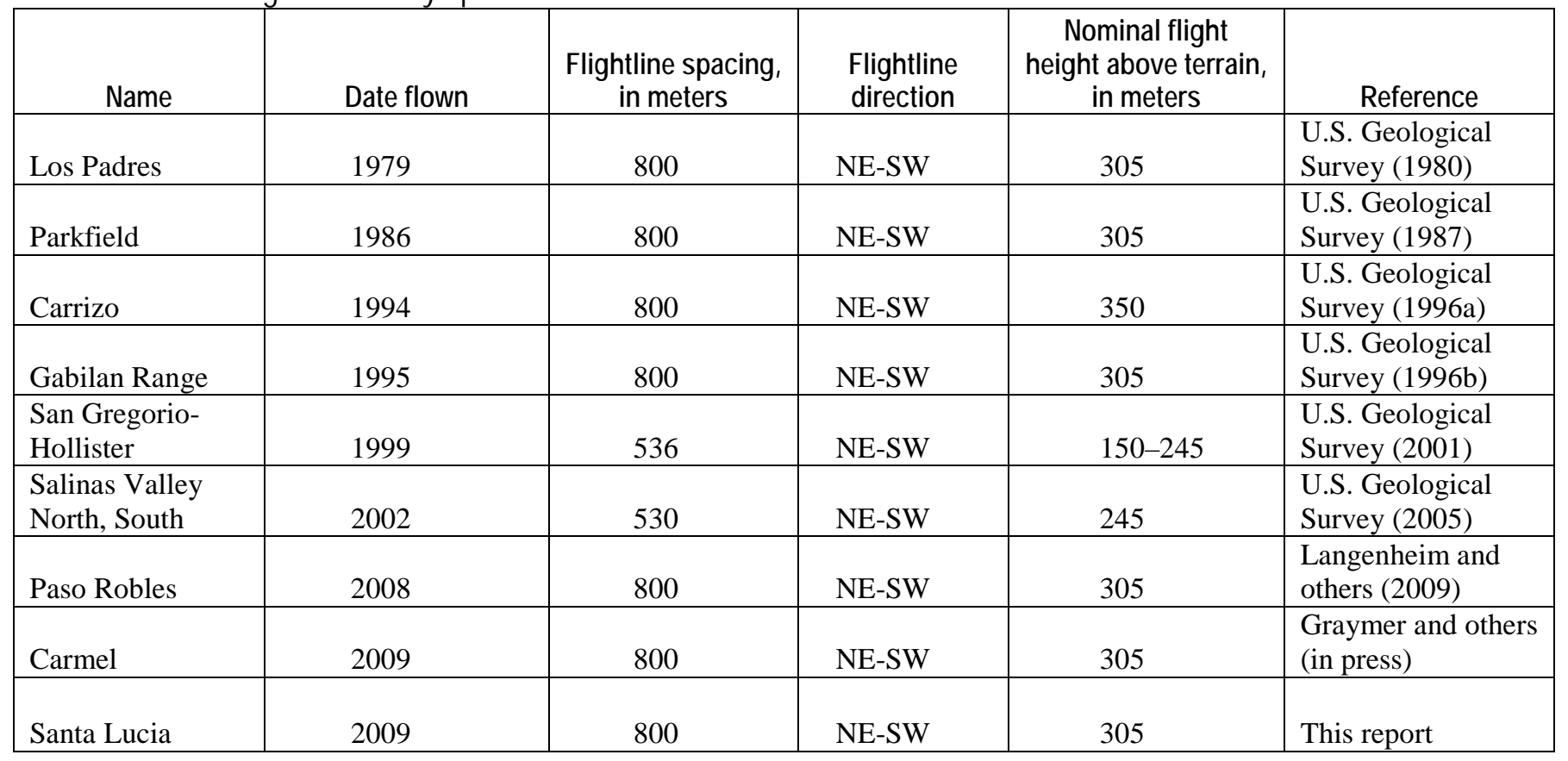

